\title{
Intestinal Dysbiosis and Potential Consequences of Microbiome-altering Antibiotic Use in the Pathogenesis of Human Rheumatic Disease
}

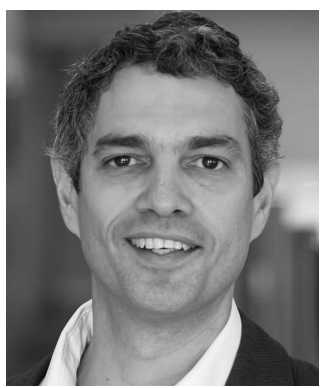

The etiopathogenesis of chronic, rheumatic autoimmune disorders has been the focus of intense research since their initial literary description. Despite much scientific iteration, the current hypothesis postulates that the natural history of most such diseases is complex and multifactorial. Ultimately, it is thought that both genetic factors (including epigenetic) and environmental influences determine the fate of predisposed subjects, who then develop clinically evident disease.

The modern notion that autoimmune arthritides are the result of polygenic interactions dates back to the mid-1970s when it was shown that HLA-B27 conferred a high risk for classic ankylosing spondylitis (AS) ${ }^{1}$, followed by the description of the shared epitope hypothesis in 1987, which posited that HLA class II alleles, particularly DR- $\beta 1$, conferred higher risk for the development of rheumatoid arthritis (RA) ${ }^{2}$. This, along with the advent of the Human Genome Project and the upsurge of genome-wide association studies, had led to an overly optimistic and, arguably, reductionist understanding of the etiology of inflammatory arthropathies. The last 3 decades have seen an ever-expanding use of high-throughput DNA sequencing by multiple groups in a quest to ascribe risk-alleles to the various autoimmune and rheumatic syndromes. This effort has resulted in, among other advances, the identification of many HLA and non-HLA risk alleles associated with disease and the emergence of a functional genomics approach to discovery and validation of immune pathways and molecular mechanisms implicated in the pathogenesis of these disorders ${ }^{3,4}$.

Although the influence of heritability for many of these arthritides is considerable, current genetic discoveries can only explain up to $20 \%$ of the variance in RA and in juvenile idiopathic arthritis (JIA) $)^{3,4}$. These include many HLA alleles (particularly HLA-A2, HLA-DR5, and HLA-DR8), and a handful of non-HLA loci (i.e., PTPN22, MI, SLC11A6, and WISP3). Importantly, mendelian patterns of inheritance have not been observed in JIA, multicase families are infrequent, and only $13 \%$ of cases of JIA can be attributed to familial factors ${ }^{5}$. Moreover, only a handful of studies have reported on the JIA concordance rate in monozygotic twins, which has been calculated to be around $25 \%{ }^{6}$. Taken together, these data necessarily leave room for environmental triggers for disease incidence in JIA. Multiple nongenetic influences have been implicated in the pathogenesis of JIA, including breastfeeding, maternal smoking, and levels of Vitamin $\mathrm{D}^{7}$. Chief among those environmental factors, however, are infectious agents and their antigenic determinants, which have been linked to JIA for a long time. An association with both viral and bacterial agents has been postulated, although none have proven causality. There are several reports on JIA initiation or flares coinciding with contraction of rubella, Epstein-Barr virus, influenza A, and parvovirus B19 viruses ${ }^{8,9,10}$. Bacterial infections, most notably with Mycoplasma pneumoniae, have temporarily correlated with the emergence of JIA cases ${ }^{11}$.

In this issue of The Journal, Arvonen, et al performed a study using the Finnish national registry to answer the question of whether repeated childhood exposure to antibiotic therapy is associated with the risk of JIA ${ }^{12}$.

In a case-control design, the authors analyzed data on antibiotic purchases from $\sim 1300$ children with JIA and $\sim 5000$ controls as surrogate for use. They demonstrated a modest association of JIA diagnosis with overall use of antibiotics (no. purchases from birth to index), and a much stronger effect with the use of lincosamides. This is indeed the first report aimed at describing this association and the authors offer 2 plausible explanations. The first is that this could be simply the result of an increased susceptibility to infections in this immunosuppressed population. Alternatively, they suggest, antibiotic use may alter the relative composition of intestinal microorganisms, ultimately leading to mucosal activation of immune response and systemic autoimmunity in the form of JIA.

See Antibiotics in JIA, page 521

Personal non-commercial use only. The Journal of Rheumatology Copyright (C) 2015. All rights reserved. 
The notion that gut-residing bacteria could be responsible for the development of autoimmune arthritis is not novel. The toxemic factor hypothesis, for example, was proposed at the turn of the 20th century, and postulated that gram-negative, anaerobic microorganisms in the gut lumen produced a proinflammatory noxious molecule that, once absorbed, led to the development of $\mathrm{RA}^{13}$. Evidence supporting this derives from decades of work in both animal models and human research ${ }^{14}$.

Multiple studies using arthritis-prone mice (and rats) demonstrated the requirement of intestinal bacteria for disease emergence, because animals raised under germ-free conditions (voided of all microorganisms) do not develop synovitis and systemic disease. In fact, this is the case in HLA-B27 transgenic rats ${ }^{15}$, SKG mice (ZAP-70 single point mutation $)^{16}$, interleukin 1 receptor antagonist animals ${ }^{17}$, and the serum-transfer model $\mathrm{K} / \mathrm{BxN}^{18}$, among others. The immune mechanisms underlying these events are continuously being studied, and the current understanding is that gut bacteria-derived antigens are specifically recognized by lamina propria dendritic cells, which in turn activate Th17 and other innate and adaptive immune cells, leading to local and systemic proinflammatory events ${ }^{19,20}$

With this as background, a novel field of research recently emerged to better understand the human microbiome, a term attributed to Joshua Lederberg, a Nobel Prize-winning American geneticist and microbiologist, to describe the totality of microorganisms (including their genes and enzymatic machinery) residing in and on us. Both the US National Institutes of Health Human Microbiome Project and the European MetaHit consortium were created (and funded) to better understand the role of the microbiome in health and disease states, with special emphasis on chronic autoimmune disorders. Novel high-throughput DNA sequencing methodologies, together with ever-expanding bioinformatics and computational capabilities, now allow for recognition of bacterial taxons without the need for tedious, inefficient culturing approaches. These efforts have led to several studies showing gut microbiome alterations (a term known as dysbiosis) characterizing multiple autoimmune rheumatic conditions, including $\mathrm{RA}^{21}, \mathrm{AS}^{22}$, and psoriatic arthritis ${ }^{23}$. One such report specifically identified a decrease in Faecalibacterium prausnitzii in the stool of children with enthesitis-related arthritis compared to controls ${ }^{24}$.

Although these studies have provided extremely relevant insights into the role of the microbiome in mucosal biology and systemic autoimmunity, several steps will need to be undertaken to go beyond correlative associations. Research efforts will necessarily require translational and multi-disciplinary approaches, including the use of gnotobiotic experiments under germ-free conditions coupled with prospective, longitudinal human cohort investigations in both the preclinical and clinical phases of disease. Crucially, the identification of potential triggering microorganisms (and its biological consequences) demands efforts to enroll patients at the very onset of disease, and prior to the use of steroidal and immunosuppressive medications. The ultimate goal is to identify potentially targetable triggering microorganisms, molecular predictors of disease, and response to therapy. All the while, Arvonen, et al ${ }^{12}$ remind us of the sometimes indiscriminate use of antibiotics in the pediatric population, a practice not free of severe health consequences, such as the epidemics of Clostridium difficile infections ${ }^{25}$, the emergence of ever more virulent resistant bacteria and perhaps too, the development of rheumatic disease.

\author{
JOSE U. SCHER, MD \\ New York University School of Medicine; \\ and Hospital for Joint Diseases \\ Department of Medicine, 301 E. 17th St. \\ New York 10003, New York, USA; \\ E-mail: jose.scher@nyumc.org
}

\section{REFERENCES}

1. Brewerton DA, Hart FD, Nicholls A, Caffrey M, James DC, Sturrock RD. Ankylosing spondylitis and HL-A 27. Lancet 1973;1:904-7.

2. Gregersen PK, Silver J, Winchester RJ. The shared epitope hypothesis. An approach to understanding the molecular genetics of susceptibility to rheumatoid arthritis. Arthritis Rheum 1987;30:1205-13.

3. Cobb JE, Hinks A, Thomson W. The genetics of juvenile idiopathic arthritis: current understanding and future prospects. Rheumatology 2014;53:592-9.

4. Okada Y, Wu D, Trynka G, Raj T, Terao C, Ikari K, et al. Genetics of rheumatoid arthritis contributes to biology and drug discovery. Nature 2014;506:376-81.

5. Prahalad S, Zeft AS, Pimentel R, Clifford B, McNally B, Mineau GP, et al. Quantification of the familial contribution to juvenile idiopathic arthritis. Arthritis Rheum 2010;62:2525-9.

6. Savolainen A, Saila H, Kotaniemi K, Kaipianen-Seppanen O, Leirisalo-Repo M, Aho K. Magnitude of the genetic component in juvenile idiopathic arthritis. Ann Rheum Dis 2000;59:1001.

7. Ellis JA, Munro JE, Ponsonby AL. Possible environmental determinants of juvenile idiopathic arthritis. Rheumatology 2010;49:411-25

8. Weissbrich B, Suss-Frohlich Y, Girschick HJ. Seroprevalence of parvovirus B19 IgG in children affected by juvenile idiopathic arthritis. Arthritis Res Ther 2007;9:R82.

9. Massa M, Mazzoli F, Pignatti P, De Benedetti F, Passalia M, Viola $\mathrm{S}$, et al. Proinflammatory responses to self HLA epitopes are triggered by molecular mimicry to Epstein-Barr virus proteins in oligoarticular juvenile idiopathic arthritis. Arthritis Rheum 2002;46:2721-9.

10. Chantler JK, Tingle AJ, Petty RE. Persistent rubella virus infection associated with chronic arthritis in children. N Engl J Med 1985;313:1117-23.

11. Rigante D, Bosco A, Esposito S. The etiology of juvenile idiopathic arthritis. Clin Rev Allergy Immunol 2014 Nov 12 (E-pub ahead of print).

12. Arvonen M, Virta LJ, Pokka T, Kröger L, Vähäsalo P. Repeated exposure to antibiotics in infancy: a predisposing factor for juvenile

Personal non-commercial use only. The Journal of Rheumatology Copyright (C) 2015. All rights reserved. 
idiopathic arthritis or a sign of this group's greater susceptibility to infections? J Rheumatol 2015;42:521-6.

13. Warden CC. The toxemic factor in rheumatoid arthritis. Cal State J Med 1909;7:299-301.

14. Scher JU, Abramson SB. The microbiome and rheumatoid arthritis. Nat Rev Rheumatol 2011;7:569-78.

15. Rath HC, Herfarth HH, Ikeda JS, Grenther WB, Hamm TE Jr., Balish E, et al. Normal luminal bacteria, especially Bacteroides species, mediate chronic colitis, gastritis, and arthritis in HLA-B27/human beta2 microglobulin transgenic rats. J Clin Invest 1996;98:945-53

16. Hida S, Miura NN, Adachi Y, Ohno N. Cell wall beta-glucan derived from Candida albicans acts as a trigger for autoimmune arthritis in SKG mice. Biol Pharm Bull 2007;30:1589-92.

17. Abdollahi-Roodsaz S, Joosten LA, Koenders MI, Devesa I, Roelofs MF, Radstake TR, et al. Stimulation of TLR2 and TLR4 differentially skews the balance of $\mathrm{T}$ cells in a mouse model of arthritis. The J Clin Invest 2008;118:205-16.

18. Wu HJ, Ivanov II, Darce J, Hattori K, Shima T, Umesaki Y, et al. Gut-residing segmented filamentous bacteria drive autoimmune arthritis via T helper 17 cells. Immunity 2010;32:815-27.

19. Littman DR, Pamer EG. Role of the commensal microbiota in normal and pathogenic host immune responses. Cell Host Microbe 2011;10:311-23
20. Yang Y, Torchinsky MB, Gobert M, Xiong H, Xu M, Linehan JL, et al. Focused specificity of intestinal TH17 cells towards commensal bacterial antigens. Nature 2014;510:152-6.

21. Scher JU, Sczesnak A, Longman RS, Segata N, Ubeda C, Bielski C, et al. Expansion of intestinal Prevotella copri correlates with enhanced susceptibility to arthritis. Elife 2013;2:e01202.

22. Costello ME, Ciccia F, Willner D, Warrington N, Robinson PC, Gardiner B, et al. Intestinal dysbiosis in ankylosing spondylitis. Arthritis Rheumatol 2014 Nov 21 (E-pub ahead of print).

23. Scher JU, Ubeda C, Artacho A, Attur M, Isaac S, Reddy SM, et al. Decreased bacterial diversity characterizes the altered gut microbiota in patients with psoriatic arthritis, resembling dysbiosis in inflammatory bowel disease. Arthritis Rheumatol 2015; 67:128-39.

24. Stoll ML, Kumar R, Morrow CD, Lefkowitz EJ, Cui X, Genin A, et al. Altered microbiota associated with abnormal humoral immune responses to commensal organisms in enthesitis-related arthritis. Arthritis Res Ther 2014;16:486.

25. Schutze GE, Willoughby RE, Committee on Infectious Diseases, American Academy of Pediatrics. Clostridium difficile infection in infants and children. Pediatrics 2013;131:196-200.

J Rheumatol 2015;42:355-7; doi:10.3899/jrheum.150036 